\title{
Mites (Acari: Mesostigmata) inhabiting nests of the white-tailed sea eagle Haliaeetus albicilla (L.) in Poland
}

\author{
Dariusz J. Gwiazdowicz, Jerzy Błoszyk, Daria Bajerlein, Robert B. Halliday \\ \& Tadeusz Mizera
}

Gwiazdowicz, D. J., Błoszyk, J., Bajerlein, D., Halliday, R. B. \& Mizera, T. 2006: Mites (Acari: Mesostigmata) inhabiting nests of the white-tailed sea eagle Haliaeetus albicilla (L.) in Poland. — Entomol. Fennica 17: 366-372.

During 1997-2002, 105 samples of mites were collected from 34 nests of the white-tailed sea eagle in Poland. The material included 9,724 specimens of Mesostigmata belonging to 86 species. The mite communities were dominated by species of the families Parasitidae, Macrochelidae and Ascidae. The most abundant species were Alliphis halleri, Androlaelaps casalis, Parasitus fimetorum and Macrocheles merdarius that altogether made up $48 \%$ of all the specimens collected. Alliphis halleri and Androlaelaps casalis were also the two most frequently found mites. A summary is presented on the biology and distribution of the abundant species.

D. J. Gwiazdowicz, Department of Forest and Environment Protection, August Cieszkowski Agricultural University, Wojska Polskiego 71C, 60-625 Poznań, Poland; E-mail:dagwiazd@au.poznan.pl

J. Bloszyk \& D. Bajerlein, Department of Animal Taxonomy and Ecology, Adam Mickiewicz University, Umultowska 89, 61-614 Poznań, Poland; E-mail: bajer (a)amu.edu.pl

J. Błoszyk, Natural Science Collection, Faculty of Biology, Adam Mickiewicz University, Umultowska 89,61-614 Poznań,Poland; E-mail: bloszyk@amu. edu.pl

R. B. Halliday, CSIRO Entomology, GPO Box 1700, Canberra ACT 2601, Australia; E-mail:Bruce.Halliday@csiro.au

T. Mizera, Department of Zoology, August Cieszkowski Agricultural University, Wojska Polskiego 71C,60-625 Poznań,Poland;E-mail:tmizera@au.poznan.pl

Received 29 October 2005, accepted 5 December 2005

\section{Introduction}

Birds' nests provide microhabitats that are inhabited by diverse groups of invertebrates, especially arthropods (Fenda \& Pinowski 1997, Fenda et al. 1998, Fenda \& Schniererová 2004, Krumpál et al. 2000-2001, Cyprich et al. 2000, Tryjanowski et al. 2001). Many of these species are potential carriers of disease for both animals and humans. However, the mite fauna of the nests of large birds of prey is poorly known, mainly as a result of the difficulty in collecting material.

The relationships among a host bird, its ectoparasites, and the accompanying fauna occupying the nest are based on a combination of specific trophic and environmental factors and phoretic 
associations. Clear co-evolutionary links among components of the resulting fauna can sometimes be discerned. In a particular area there may be parallel adaptations of the host to life in the prevailing local environmental conditions, of the parasites to a given host species, in regard to both the host and its nest, and the transformation of free-living arthropod species into specific nidicoles that are adapted to life in this specific microhabitat (Vysotskaya \& Daniel 1973). These factors would suggest that the nests of different species of birds that have different patterns of behaviour with respect to nest building could produce differing faunas of nidicolous mites. In the present paper we examine this phenomenon by surveying the mite fauna of the nests of the whitetailed sea eagle Haliaeetus albicilla, which has a quite different pattern of nesting behaviour from the white stork Ciconia ciconia, which we have examined previously (Błoszyk et al. 2005). In particular, the nests of the white-tailed sea eagle create for invertebrates a specific niche that is characterised by less seasonal variation than those of the white stork.

The large, old nests of the white-tailed sea eagle - the largest Polish bird of prey - are an interesting subject for research. Our earlier observations (Gwiazdowicz et al. 2005) showed that the species composition and community structure of the Mesostigmata in these nests are highly variable over successive years of nesting. The breeding season of the eagle begins in the spring, during February-March, earlier than that of the white stork, and the eagle does not seasonally abandon its nest. It is associated with aquatic environments and occurs near lakes, fish ponds and river valleys where it can feed, build nests, and live after the breeding season. During winter the eagles concentrate around rivers and flood plains. In Poland, the nests of the white-tailed sea eagle are situated exclusively in trees, most frequently in old pines and beeches. The nest is systematically built up over many years and reaches a size of up to $4 \mathrm{~m}$ in height and $2.5 \mathrm{~m}$ in diameter. Its mass can reach as much as $1,000 \mathrm{~kg}$. One-yearold nests are considerably smaller, about $0.6 \mathrm{~m}$ high and $0.8-1.2 \mathrm{~m}$ in diameter. A single pair of eagles may have one or more nests, usually $2-3$. The birds remain near their nests throughout the year. Nests built by the eagle are isolated from each other and from other habitats that are commonly inhabited by mites, such as forest litter and soil. It is therefore interesting to study the dispersal mechanisms that allow mites to move into nests or from one nest to another.

The work presented here continues a study on the mite fauna of avian nests in Poland. Previous papers in this series are Błoszyk \& Olszanowski (1985, 1986), Tryjanowski et al. (2001), Błoszyk et al. (2005), and Gwiazdowicz et al. (2005). Here, we aim at describing the mite fauna associated with the nests of the white-tailed sea eagle.

\section{Material and methods}

Between 1997 and 2002, we collected 105 samples from 34 nests of the white-tailed sea eagle from different parts of Poland. Samples of nest material, each $0.5-0.81$, were collected during May and June each year. The material was extracted in Tullgren funnels for 7 days and the collected mites were preserved in $75 \%$ ethyl alcohol. Specimens were cleared in lactic acid or lactophenol and identified using the keys of Karg $(1989,1993)$. Values of the dominance $(D)$ and occurrence coefficient $(C)$ were calculated following Błoszyk (1999). The dominance coefficient $D$ is a measure of the relative abundance of each species, calculated as $D=\left(n_{\mathrm{a}} / n\right) * 100$, where $n_{\mathrm{a}}=$ number of specimens of species a in all samples, and $n=$ total number of specimens of all species in all samples.

The occurrence coefficient $C$ is a measure of the frequency with which each species is found in the collected samples, calculated as $C=(q / Q)$ * 100 , where $q=$ the number of samples in which a particular species occurred, and $Q=$ total number of samples. Regarding dominance $(D)$, species were grouped into the following classes: eudominant (D5), $>30.0 \%$; dominant (D4), 15.1$30.0 \%$; subdominant (D3), 7.1-15.0\%; recedent (D2), 3.0-7.0\%; and subrecedent (D1), $<3.0 \%$. For frequency $(C)$, species were grouped into euconstant (C5), >50.0\%; constant (C4), 30.1$50.0 \%$; subconstant (C3), 15.1-30.0\%; accessory species (C2), 5.0-15.0\%; and accidental species (C1),$<5.0 \%$.

All the material is deposited in "The Invertebrate Fauna Bank", Department of Animal Tax- 
onomy and Ecology, Adam Mickiewicz University, Poznań, Poland.

\section{Results}

The study yielded a total of 9,724 specimens of Mesostigmata belonging to 86 species, including representatives of the suborders Gamasina ( 78 species) and Uropodina (8 species) (Table 1). Among the species represented, 13 were characterised by a high dominance coefficient. A short description of 10 of them is given below, citing their geographical distribution and most commonly occupied microhabitats. Parasitus fimetorum, Macrocheles glaber and M. merdarius were also abundant, but accounts on the biology of these species have already been presented in the paper on mites in white stork nests (Błoszyk et al. 2005).

\section{Cornigamasus lunaris (Berlese, 1882)}

A species found in compost, decomposing organic material, excrement, and the nests of ants, such as Lasius fuliginosus (Hyatt 1980; Karg 1993). It occurs all over Europe.

\section{Macrocheles ancyleus Krauss, 1970}

Found in dead wood, and also in old nests of birds of prey (Krauss 1970, Gwiazdowicz et al. 1999, Gwiazdowicz 2003b, Mašán 2003). So far known only from Central Europe.

\section{Alliphis halleri (G. \& R. Canestrini, 1881)}

Most commonly found in decomposing organic material, compost and excrement (Karg 1993). The species occurs in Europe and Asia.

\section{Proctolaelaps pygmaeus (Müller, 1860)}

A cosmopolitan species that occurs in soil, moss, decomposing organic material and in the nests of small mammals (Bregetova 1977b).

\section{Iphidozercon gibbus Berlese, 1903}

A species most frequently found in soil, forest litter, humus and in the nests of small mammals (Bregetova 1977b). Occurs in Europe and in North Africa.
Androlaelaps casalis (Berlese, 1887)

A species found in forest litter, humus, and soil, but most commonly in the nests of small mammals and birds (Karg 1993). Occurs in the entire Palaearctic region and North America.

\section{Dendrolaelaps strenzkei Hirschmann, 1960}

This species has been found, among other places, in rotting wood, under bark, in the nests of Formica rufa ants, and also in soil, forest litter and compost (Hirschmann \& Wiśniewski 1982, Karg 1993). It occurs all over Europe, from Italy in the South, to Finland in the North, from Spain in the West, to Russia in the East.

\section{Uroseius infirmus (Berlese, 1887)}

A species found in decomposing plant remains, tree trunks and tree holes, but most commonly in birds' nests, with known phoresy on beetles (Wiśniewski \& Hirschmann 1993, Mašán 2001, Błoszyk et al. 2005). Its range includes Europe, Kazakhstan and Mongolia.

Nenteria pandioni Wiśniewski \& Hirschmann, 1985

A species most commonly occurring in old birds' nests (Gwiazdowicz et al. 2000, Gwiazdowicz 2003a). The species has been found in Poland and Slovakia.

Trichouropoda ovalis (C. L. Koch, 1839)

This species has been found in many micro-habitats, such as among mosses, forest litter, mushrooms, rotting wood, tree holes, insect nests and burrows, and the nests of mammals and birds (Wiśniewski \& Hirschmann 1993; Błoszyk 1999). A widespread European species.

\section{Discussion}

The nests of the white-tailed sea eagle contain an exceptionally rich fauna of Mesostigmata. The number of species in these nests is much greater than in the nests of any other bird species reported in previous studies on mite faunas of avian nests. This is a result not only of the large number of nests examined, but also because the nests of the white-tailed sea eagle are genuinely characterised by a high degree of acarofauna species variabil- 
Table 1. List of mite species occurring in the nests of Haliaeetus albicilla. Legend: $F$ - female, $M$ - male, D - deutonymph, P protonymph, L-larva, D\% - dominance, C\% - occurrence coefficient.

\begin{tabular}{llllllllllll}
\hline Taxon & Total & F & M & D & P & L & D $\%$ & C $\% ~$
\end{tabular}

ANTENNOPHORINA

\section{Celaenopsidae}

(1)

Celaenopsis badius C. L. Koch, 1839

GAMASINA

\section{Zerconidae}

Prozercon kochi Sellnick, 1943

Zercon curiosus Trägírdh, 1910

Zercon peltatus peltatus C. L. Koch, 1836

Zercon triangularis C. L. Koch, 1836

Zercon zelawaiensis Sellnick, 1944

\section{Parasitidae}

Cornigamasus lunaris (Berlese, 1882)

Parasitus coleoptratorum (Linnaeus, 1758)

Parasitus consanguineus

Voigts \&d Oudemans, 1904

Parasitus fimetorum (Berlese, 1904)

Parasitus mustelarum Oudemans, 1903

Poecilochirus carabi G. \& R. Canestrini, 1882

Vulgarogamasus kraepelini (Berlese, 1904)

Holoparasitus calcaratus (C. L. Koch, 1839)

Paragamasus brevipes (Berlese, 1905)

Paragamasus misellus (Berlese, 1903)

Paragamasus runciger (Berlese, 1903)

Paragamasus vagabundus (Karg, 1968)

Pergamasus brevicornis Berlese, 1903

Pergamasus mediocris Berlese, 1904

\section{Macrochelidae}

Geholaspis longispinosus (Kramer, 1876)

Macrocheles ancyleus Krauss, 1970

Macrocheles carinatus (C. L. Koch, 1839)

Macrocheles copridis Mašán, 2003

Macrocheles decoloratus (C. L. Koch, 1839)

Macrocheles glaber (Müller, 1860)

Macrocheles merdarius (Berlese, 1889)

Macrocheles muscaedomesticae (Scopoli, 1771)

Macrocheles penicilliger (Berlese, 1904)

\section{1}

$1-$

1

1
2
27
3
2

Macrocheles perglaber Filipponi \& Pegazzano, 1962

Macrocheles rotundiscutis Bregetova \& Koroleva, 1960

Macrocheles tridentinus (G. \& R. Canestrini, 1882)

Macrocheles sp.

\section{Eviphididae}

Alliphis halleri (G. \& R. Canestrini, 1881)

\section{Ascidae}

Arctoseius elegans Bernhard, 1963

Arctoseius insularis (Willmann, 1952)

Arctoseius semiscissus (Berlese, 1892)

Asca aphidioides (Linnaeus, 1758)

Asca bicornis (Canestrini \& Fanzago, 1887)

Blattisocius dentriticus (Berlese, 1918)

Gamasellodes bicolor (Berlese, 1918)

Iphidozercon corticalis Evans, 1958

Iphidozercon gibbus Berlese, 1903

Lasioseius furcisetosus Athias-Henriot, 1961

37
8

50

1132

21

3

20

1

50

11

17

2

12

626

626
2

4

0.01

0.95

0.95

0.95

5.71

0.95

0.95

$3.87 \quad 11.43$

$0.83 \quad 5.71$

0.51

11.64

0.22

0.03

0.21

0.01

0.13

0.51

0.11

0.17

0.02

0.12

5.71

29.52

4.76

1.90

2.86

0.95

0.95

0.95

0.95

3.81

1.90

0.95

$0.02 \quad 1.90$

$6.44 \quad 23.81$

0.02

0.04

0.11

2.64

11.64

0.13

0.11

0.37

0.04

0.02

0.46

0.95

0.95

0.95

26.67

24.76

0.95

0.95

3.81

0.95

1.90

1.90

37.14

$0.03 \quad 0.95$

$0.01 \quad 0.95$

$0.14 \quad 0.95$

$0.01 \quad 0.95$

$0.12 \quad 3.81$

$0.02 \quad 1.90$

$0.01 \quad 0.95$

$1.09 \quad 2.86$

$0.04 \quad 0.95$
$0.12 \quad 3.81$ 
Taxon

Total

F M

D

$\mathrm{L}$

$\mathrm{D} \%$

$\mathrm{C} \%$

Lasioseius ometes (Oudemans, 1903)

Lasioseius ometisimilis Hirschmann, 1963

Lasioseius youcefi Athias-Henriot, 1959

Leioseius minusculus Berlese, 1905

Leioseius sp.

Neojordensia sinuata Athias-Henriot, 1973

Proctolaelaps hystrix (Vitzthum, 1923)

Proctolaelaps pygmaeus (Müller, 1860)

\section{Laelapidae}

Eulaelaps stabularis (C. L. Koch, 1839)

Haemogamasus horridus Michael, 1892

Androlaelaps casalis (Berlese, 1887)

Hypoaspis austriacus Sellnick, 1935

Hypoaspis brevipilis Hirschmann 1969

Hypoaspis lubrica Voigts \& Oudemans, 1904

Hypoaspis oblonga (Halbert, 1915)

Dermanyssidae

Dermanyssus gallinae De Geer, 1778

Veigaiidae

Gamasolaelaps excisus (C. L. Koch, 1879)

Veigaia nemorensis (C. L. Koch, 1839)

Halolaelapidae

Halolaelaps sp.

Pachylaelapidae

Pachylaelaps furcifer Oudemans, 1903

\section{Digamasellidae}

Dendrolaelaps arvicolus (Leitner, 1949)

Dendrolaelaps fallax (Leitner, 1949)

Dendrolaelaps latior (Leitner, 1949)

Dendrolaelaps longiusculus (Leitner, 1949)

Dendrolaelaps presepum (Berlese, 1918)

Dendrolaelaps strenzkei Hirschmann, 1960

Dendrolaelaps wengrisae Wiśniewski, 1979

Dendrolaelaps zwoelferi Hirschmann, 1960

\section{Ameroseiidae}

Ameroseius apodius (Karg, 1971)

Ameroseius corbiculus (Sowerby, 1806)

Ameroseius longitrichus Hirschmann, 1963

Ameroseius sp.

Phytoseiidae

Amblyseius sp.

Typhlodromus pyri Scheuten, 1857

UROPODINA

\section{Polyaspidae}

Uroseius infirmus (Berlese, 1887)

\section{Trematuridae}

Nenteria pandioni Wiśniewski \& Hirschmann, 1985

Trichouropoda orbicularis (C. L. Koch, 1839)

Trichouropoda ovalis (C. L. Koch, 1839)

Urodinychidae

Dinychus sp.

Uroobovella marginata (C. L. Koch, 1839)

Uroobovella pyriformis (Berlese, 1920)

\section{Uropodidae}

Uropoda orbicularis (Müller, 1776)

2
1
1
10
2
1
4
642

-
-
-
-
1
-
-
1

1213

1
29

1

1

$$
1
$$

(1)

3

947

2
1
9
-
1
4
9

-
-
-
1
-
-
-
2

$\begin{array}{ll}- & - \\ - & - \\ - & - \\ - & - \\ - & - \\ - & -\end{array}$

$\begin{array}{ll}- & 0.02 \\ - & 0.01 \\ - & 0.01 \\ - & 0.10 \\ - & 0.02 \\ - & 0.01 \\ - & 0.04 \\ - & 6.60\end{array}$

1.90

0.95

0.95

0.95

1.90

0.95

0.95

28.57

- $\quad$ - 0.03

1.90

0.95

46.67

$\begin{array}{lll}10 & 32 & 12.47\end{array}$

0.01

0.30

0.01

0.01

0.95

2.86

0.95

0.95

0.01

0.95

0.32

0.06

0.95

3.81

4.96

12.38$$
-
$$$$
-
$$$$
-
$$$$
1
$$$$
-
$$$$
38
$$$$
100
$$$$
-
$$

0.01

0.45

0.14

0.03

0.04

1.68

0.02

0.01

0.95

9.52

1.90

1.90

0.04

17.14

0.95

0.95

0.77

0.01

3.81

0.95

0.95

2.86

0.05

0.95

0.02

0.95
0.95

773

22

624

3
124

$\begin{array}{rrr}169 & 120 & 265 \\ 2 & - & - \\ 48 & 48 & 21\end{array}$

360
265
-
21

7

7.95

26.67

6.42

31.43

$0.03 \quad 1.90$

$\begin{array}{ll}1.28 & 20.95\end{array}$

2

1
7

11

1

0.02

0.95

$0.01 \quad 0.95$

7

2

0.07

0.95

45

$\begin{array}{lll}9 & 5 & 29\end{array}$

2

0.46

6.67 
ity, even over a short period of time (Gwiazdowicz et al. 2005).

The species composition and community structure of the Mesostigmata found in the whitetailed sea eagle nests are clearly different from those encountered in white stork nests, even though both build nests that are maintained for many years (Błoszyk et al. 2005). Many species occurring in great numbers in the eagle nests have not been found in stork nests. An example is Alliphis halleri that was the most abundant species in the eagle nests but was not found at all in the nests of the white stork. Androlaelaps casalis was also very numerous in the eagle nests, but was infrequent and never abundant in stork nests. Cornigamasus lunaris (Parasitidae) occurred in high numbers in the nests of the white-tailed sea eagle (Table 1), and it has been reported as being abundant also in the nests of other birds of prey (Gwiazdowicz 2003a), but it is considered uncommon in the nests of the white stork (Błoszyk et al. 2005). Similarly, Macrocheles ancyleus (Macrochelidae) has been found mainly in the nests of birds of prey (Gwiazdowicz et al. 1999; Gwiazdowicz 2003a, present study), whereas in the nests of other bird species it has been recorded only sporadically.

The most species-rich mite families in the nests of the white-tailed sea eagle were Parasitidae (14 species), Macrochelidae (13 species) and Ascidae (18 species). The rich fauna of Ascidae is particularly striking, because they have only rarely been found in avian nests before. Proctolaelaps pygmaeus has been found in bird nests before, but never in great numbers (Fenda $e t$ al. 1998). The same is true for Iphidozercon gibbus that has most frequently been found in soil environments. It is also worth noting the occurrence of great numbers of Ameroseius apodius (75 individuals). This species is most commonly found in forest litter and compost heaps (Bregetova 1977a). In Poland it has been observed only sporadically, usually as sigletons.

Species regarded as being parasitic occurred in the eagle nests only sporadically and never in great numbers, even though over 100 samples were taken: Eulaelaps stabularis (3 individuals), Haemogamasus horridus (2 individuals) and Dermanyssus gallinae (1 individual). Compared to the nests of swallows - where the number of parasitic mites can be very high - the small number of parasites in the nests of the white-tailed sea eagle is peculiar. It is perhaps most likely connected to the unfavourable micro-climatic conditions that can have a direct influence on the fauna inhabiting an open nest.

The presence of species that are known to most frequently occur in soil (e.g. Zercon spp., Paragamasus spp. and Pergamasus spp.), live in rotting wood, or be associated with other insects (e.g. Dendrolaelaps spp.), can be explained by specimens being carried by the bird to the nest together with the nest-building material. This may also explain the presence of many mite species represented by singletons. Many of these mite species occur perhaps most frequently on the soil surface or in dead wood.

Acknowledgements. This work was supported by a grant from the Ministry of Education (Research Project No. 2 P06L 048 28).

\section{References}

Błoszyk, J. 1999: Geograficzne i ekologiczne zróżnicowanie roztoczy z kohorty Uropodina (Acari: Mesostigmata) w Polsce. I. Uropodina lasów grądowych (Carpinion betuli). — Kontekst, Poznań 245 pp. [In Polish.]

Błoszyk, J. \& Olszanowski, Z. 1985: Materiały do znajomości roztoczy gniazd i budek lęgowych ptaków. I Uropodina i Nothroidea (Acari: Mesostigmata i Oribatida). - Przeg. Zool. 29: 69-74. [In Polish.]

Błoszyk, J. \& Olszanowski, Z. 1986: Materiały do znajomości fauny roztoczy gniazd i budek lęgowych ptaków. II. Różnice w liczebności i składzie gatunkowym populacji Uropodina (Acari, Anactinotrichida) budek lęgowych na Mierzei Wiślanej na podstawie dwuletnich obserwacji. — Przeg. Zool. 30: 63-66. [In Polish.]

Błoszyk, J., Gwiazdowicz, D. J., Bajerlein, D. \& Halliday, R. B. 2005: Nest of the white stork Ciconia ciconia (L.) as a habitat for mesostigmatic mites (Acari, Mesostigmata). - Acta Parasitol. 50: 171-175.

Bregetova, N. G. 1977a: Ameroseiidae. - In: Gilarov, M. S. \& Bregetova, N. G. (eds.), Opredelitel' obitayushchikh $\mathrm{v}$ pochve kleshchei Mesostigmata:148169. Nauka, Leningrad.

Bregetova, N. G. 1977b: Aceosejidae. - In: Gilarov, M. S. \& Bregetova, N. G. (eds.), Opredelitel' obitayushchikh v pochve kleshchei Mesostigmata: 169 226. Nauka, Leningrad.

Cyprich, D., Fenda, P., Krumpál, M., Lukáš, J.\& Ambruš, B. 2000: Hniezdna fauna zebričky červenozobej (Taeniopygia guttata castanotis). [The nest fauna of 
the Zebra Finch (Taeniopygia guttata castanotis)] Tichodroma 13: 189-200. [In Czech.]

Fenda, P. \& Pinowski, J. 1997: The mites (Acarina: Mesostigmata) in the nests of sparrows (Passer domesticus and Passer montanus) in suburban villages of Warsaw (Poland). - International Studies on Sparrows 24: 37-47.

Fenda, P. \& Schniererová, E. 2004: Mites (Acarina: Mesostigmata) in the nests of Acrocephalus spp. and in neighbouring reeds. - Biologia (Bratislava) 59 (Suppl. 15): 41-47.

Fenda, P., Krumpál, M. \& Cyprich, D. 1998: The soil fauna in the birds' nests in Slovakia. - In: Pižl, V., Tajovský, K. (eds.), Soil Zoological Problems in Central Europe: 23-30. Institute of Soil Biology Academy of Sciences of the Czech Republic, České Budějovice.

Gwiazdowicz, D. J. 2003a: Mites (Acari, Mesostigmata) occurring in the nests of birds of prey (Falconiformes) and owls (Strigiformes). - Acarina, Russian Journal of Acarology 11: 235-239.

Gwiazdowicz, D. J. 2003b: Mites (Acari, Mesostigmata) appearing in Poland, in the bird's nests of Passeriformes, Falconiformes and Strigiformes orders. - In: Miler, A. T. (ed.), Kształtowanie i ochrona środowiska leśnego: 562-572. Wyd. Akademii Rolniczej, Poznań.

Gwiazdowicz, D. J., Mizera, T. \& Skorupski, M. 1999: Mites in greater spotted eagle nests. - Journal of Raptor Research 33: 257-260.

Gwiazdowicz, D. J., Mizera, T. \& Skorupski, M. 2000: Mites (Acari, Gamasida) from the nests of birds of prey in Poland. - Buteo 11: 97-100.

Gwiazdowicz, D. J., Błoszyk, J., Mizera, T. \& Tryjanowski, P. 2005: Mesostigmatic mites (Acari: Mesostigmata) in white-tailed sea eagle nest (Haliaeetus albicilla). - Journal of Raptor Research 39: $60-65$.

Hirschmann, W. \& Wiśniewski, J. 1982: Weltweite Revision der Gattungen Dendrolaelaps Halbert 1915 und Longoseius Chant 1961 (Parasitiformes). - Acarologie. Schriftenheihe für Vergleichende Milbenkunde 29: $1-48$.
Hyatt, K. H. 1980: Mites of the subfamily Parasitinae (Mesostigmata: Parasitidae) in the British Isles. Bull. Br. Mus. (Nat. Hist.) Entomol., Zoology 38: 237-378.

Karg, W. 1989: Acari (Acarina), Milben Unterordnung Parasitiformes (Anactinochaeta) Uropodina Kramer Schildkrötenmilben. - Die Tierwelt Deutschlands 67: 1-203.

Karg, W. 1993: Acari (Acarina), Milben Unterordnung Parasitiformes (Anactinochaeta) Cohors Gamasina Leach. Raubmilben. - Die Tierwelt Deutschlands 59: $1-523$.

Krauss, W. 1970: Die europäischen Arten der Gattungen Macrocheles Latreille 1829 und Geholaspis Berlese 1918. - Acarologie. Schriftenheihe für Vergleichende Milbenkunde 14: 1-60.

Krumpál, M., Cyprich, D., Fenda, P. \& Pinowski, J. 20002001: Invertebrate fauna in nests of the house sparrow Passer domesticus and the tree sparrow Passer montanus in central Poland. - International Studies on Sparrows 35-58.

Mašán, P. 2001: Roztoče kohorty Uropodina (Acari, Mesostigmata) Slovenska. - Annotationes Zoologicae et Botanicae 223: 1-320. [In Czech.]

Mašán, P. 2003: Macrochelid mites of Slovakia (Acari, Mesostigmata, Macrochelidae). - Institute of Zoology, Slovak Academy of Sciences, Bratislava. 149 pp.

Tryjanowski, P., Baraniak, E., Bajaczyk, R., Gwiazdowicz, D. J., Konwerski, S., Olszanowski, Z. \& Szymkowiak, P. 2001: Arthropods in nests of the redbacked shrike (Lanius collurio) in Poland. - Belg. J. Zool. 131: 69-74.

Wiśniewski, J. \& Hirschmann, W. 1993: Katalog der Ganggattungen, Untergattungen, Gruppen und Arten der Uropodiden der Erde. - Acarologie. Schriftenheihe für Vergleichende Milbenkunde 40: 1-220.

Vysotskaya, S. O. \& Daniel, M. K. 1973: Arthropods of the nests of small mammals. Collecting methods, microclimatic investigation. - In: Methods of Parasitologic Investigations. Nauka, Leningrad 7: 3-70. 